\title{
Monitoring and Search of Coma Patients using Variable Motion Sensor System
}

\author{
R.Kishore Kanna, N.Subhalakhsmi, V.Gomathy, R.Vasuki
}

\begin{abstract}
It is vital to consistently screen the oblivious/extreme lethargies patients to comprehend their wellbeing condition. The primary objectives of the proposed is to achieve two things.

1) Monitoring and cautioning the restorative individual is the basic part, when the incapacitated additions cognizance utilizing movement recognition framework.

2) Continuous observing and assessment of basic signs of the patient, for example, Pulse rate and warmth and alarm the specialist at whatever point consideration is required. Wearable Motion sensor framework can be utilized to screen different body developments such and hand development as visual perception flicker development to find the cognizant condition of an individual. This framework will all around likely be exceptionally useful in helping the specialist about the wellbeing state of the other than cognizant patient and cautioning the doctor at whatever point care is required. The proposed framework will help your specialist by providing an alert about the wellbeing state of the patient, when the spot of basic signs reported.
\end{abstract}

Keywords: Attention, Alerting, Coma patient, Monitoring, Motion detection, Physical movement, Vital signal.

\section{INTRODUCTION}

A trance like state is an underground government of obviousness[1-9], amid which an individual can't respond to his or her condition. Somebody in a trance like state can't intentionally react to incitement. Trance like state can be brought about by a fundamental ailment, or it can result from head injury. An incapacitated individual is still especially alive, yet the person in question isn't just sleeping. The mind wave action in a sluggish individual is altogether different from that of a dozing individual; you can awaken a dozing individual, you can't wake an individual in a state of extreme lethargy[10-16].

Unconsciousness isn't a cerebrum passing. An individual $n$ the unconsciousness state is alive yet couldn't move or react

to the earth. Trance like state can happen because of wounds, for example, head wounds or as an irritation of a fundamental

Revised Version Manuscript Received on July 18, 2019.

R.Kishore Kanna Assistant Professor,Department of Biomedical Engineering,Bharath Institute of Higher Education and Research, Chennai-600073, Tamil Nadu, India.

N.Subhalakhsmi, Assistant Professor,Department of Biomedical Engineering,Bharath Institute of Higher Education and Research, Chennai-600073, Tamil Nadu, India.

V.Gomathy, Assistant Professor,Department of Biomedical Engineering,Bharath Institute of Higher Education and Research, Chennai-600073, Tamil Nadu, India.

Dr.R.Vasuki, Assistant Professor,Department of Biomedical Engineering,Bharath Institute of Higher Education and Research, Chennai-600073, Tamil Nadu, India. sickness. People in extreme lethargies state will lose their reasoning capacities and consciousness of their environment, however will hold ordinary rest designs and non-intellectual capacity[17-25]. For a person in a tireless vegetative express the critical capacities like flow and breathing stays safe despite the fact that the individual loses his top dimension mind capacities. Once in a while the individual in a trance like state can react to the outer condition by intentional developments, for example, he may open his eyes because of outside drive. Despite the fact that a person in a trance like state seems typical however they couldn't react to the outside directions[26-35]. Since the physical movement of determined vegetative state individual are uncommon, there is a requirement for customary consideration and care. In present framework utilized in emergency clinics a medicinal services proficient is expected to consistently screen and record all the essential data of a specific subject by maintainingall the records of that torpid physically. Such techniques for constant supervision by a paramedical right hand are mistake inclined and may prompt troubles because of human blunder. In the event that there is genuinely sick patients itrequires to gauge the basic rules in any event for every single no time until the patient'scondition settles. Accordingly checking of trance like state patients is not the same as observing the ordinary patients. This is extreme duty of the paramedical staff to reliably screen every individual's 24 hours since the extent of staff to persistent is exceptionally low. So it's anything but a genuinely simple errand to watch out for each patient routinely. This sort of framework is proposed to dispose of the weight of constant supervision and will alarm the specialist or paramedical staff just when consideration is required. This strategy will be useful in helping the specialist about the patient condition whether he is steady or flimsy and will watch out for.

\section{MATERIALS AND METHODOLOGY \& RESULTS}

The proposed framework contains four sensors in which two sensors are utilized for observing vitals indications of the extreme lethargies patients. Temperature and heartbeat rate are the two vitals spared and varified to know wellbeing status of an out cold. The other two sensors are MEMS accelerometer sensor and Eyesight flicker sensor which are 
being utilized to record any physical changes that outcome from an incapacitated. These signs which gives subtleties are recorded and observed reliably to realize the body working. These arrangements of detected signs that are outside ordinary ranges ordinarily propose the requirement for some consideration or conceivable removal to the following dimension of treatment amid which we alert the specialist[36-45].



\section{SIGNIFICANCE OF THE SYSTEM}

The main advantage of the system is that it helps the blind people in both indoor and outdoor, care-free navigation. The devices placed in the stick makes it comfortable and easy to handle. The smart stick helps in detecting obstacles placed at a distance in front of the user[46-52]. The system is suitable for both indoor and outdoor environment. The information regarding obstacles is given through voice alerts, eliminates the difficulty RASPBERRY PI Ultra sonic SEN SOR Voice synthizer Batter y Micro phone Buzzer Rf receive $r$ Camera Water sensor Battery $(9 v$ dc) RF transmitter Button International Journal of Pure and Applied Mathematics Special Issue 4534 of understanding vibration patterns which was used in earlier systems. The system is a moderate budget mobile navigational aid for the visually impaired.

\section{CONCLUSION}

The smart walking stick, constructed with at most accuracy, will help the blind people to move from one place to another without others help. This could also be considered a crude way of giving the blind a sense of vision. This stick reduces the dependency of visually impaired people on other family members, friends and guide dogs while walking around. The proposed combination of various working units makes a real-time system that monitors position of the user and provides dual feedback making navigation more safe and secure. The smart stick detects objects or obstacles in front of users and feeds warning back, in the form of voice messages rather than vibration. Also the incorporation of automatic room equipment switching in the stick will be useful while they are indoor. The advantage of the system lies in the fact that it can prove to be a low cost solution to millions of blind person worldwide
Advanced Coma Patient Monitoring System

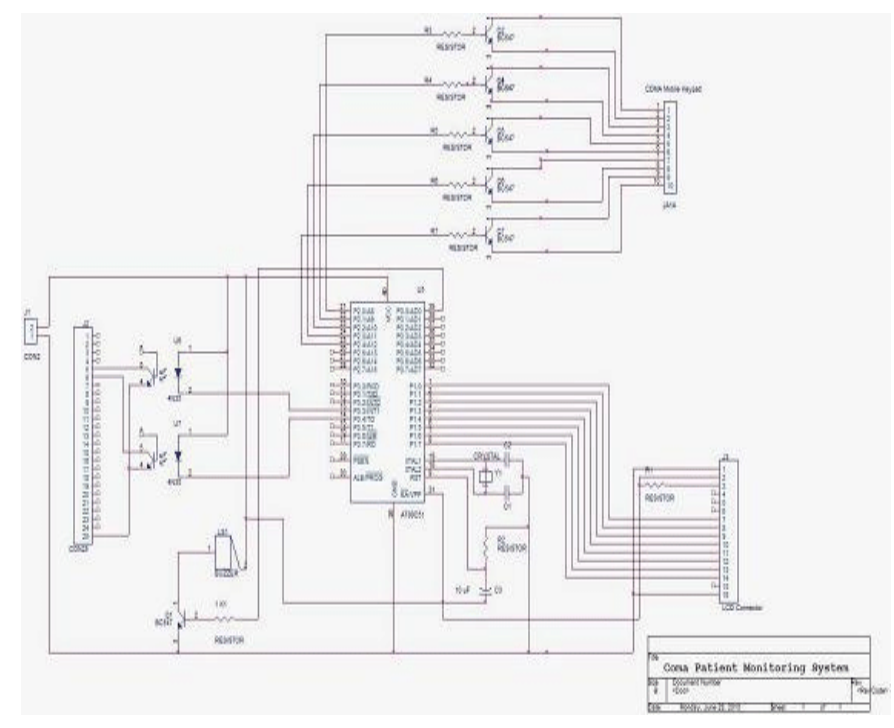

\section{REFRENCES}

1. International Journal of Scientific \& Engineering Research Volume 2, Issue 6, June- 2011 ISSN 2229-5518.

2. Malika, Charu Rana, "AnIndoor Wireless Zigbee based Patient Monitoring system for Hospitals", International Journal of Engineering Sciences Research-IJESR, Vol 04, Issue 02; March-April 2013

3. K. Navya, Dr. M. B. R. Murthy,“A Zigbee Based Patient Health Monitoring System",Int. Journal of Engineering Research and Applications, www.ijera.com, Vol. 3, Issue 5, pp.483-486, Sep- Oct 2013.

4. Amruta Chopade, Prof. Nitin Raut, "RemotePatients Health Monitoring by Using Zigbee Protocol", International Journal of Advanced Research in Computer Science and Software Engineering, Volume4, Issue 8, August 2014.

5. Xi Chen, "Human Motion Analysis with WearableInertial Sensors", University of Tennessee,Knoxville, 8-2013.

6. Khalifa AlSharqi, Abdelrahim Abdelbari, Ali Abou-

a. Elnour, and Mohammed Tarique, "Zigbee based wearable remote healthcare montoring system for elderly patients"International Journal of Wireless \& Mobile Networks (IJWMN) Vol. 6, No. 3, June 2014.

7. AmrutaNagarkar, M.N.Kakatkar, "Zigbee based wireless patient monitoring",International Journal of Science, Engineering and TechnologyResearch(IJSETR),Volume 2, Issue 2, February 2013.

8. Paula Pascoal-Faria, Miguel Patrício, Adriana Leal, Francisco Caramelo, António Freire, CristinaJanuario, Miguel Castelo-Branco, "Understanding Tremor in Rapid Upper Limb Movements Using 3DAccelerometers Data", Neuroscience \& Medicine, 2014,5, 205-213 Published Online December 2014 in SciRes.

9. Sharmila S., Jeyanthi Rebecca L., Das M.P.,Production of Biodiesel from Chaetomorpha antennina and Gracilaria corticata,Journal of Chemical and Pharmaceutical Research,V-4,I-11,PP-4870-4874,Y-2012

10. Aarthi C., Ramesh Babu P.B.,Anti-cancer activity of Phyllanthus reticulatus on colon cancer cell line, International Journal of Civil Engineering and Technology,V-8,I-1,PP-943-947,Y-2017 
11. Sharmila S., Jeyanthi Rebecca L., Das M.P., Saduzzaman M.,Isolation and partial purification of protease from plant leaves, Journal of Chemical and Pharmaceutical Research,V-4,I-8,PP-3808-3812,Y-2012

12. Jayalakshmi T., Krishnamoorthy P., Ramesh Babu P.B., Vidhya B.,Production, purification and Biochemical characterization of alkaline Fibrinolytic enzyme from Bacillus subtilisstrain-GBRC1,Journal of Chemical and Pharmaceutical Research,V-4,I-12,PP-5027-5031,Y-2012

13. Jeyanthi Rebecca L., Susithra G., Sharmila S., Das M.P.,Isolation and screening of chitinase producing Serratia marcescens from soil,Journal of Chemical and Pharmaceutical Research,V-5,I-2,PP-192-195,Y-2013

14. Aarthi C., Ramesh Babu P.B.,Antimicrobial and antioxidant activity of phyllanthus niruri,International Journal of Pharmacy and Technology, V-8,I-2,PP-14701-14707,Y-2016

15. Anbuselvi S., Jeyanthi Rebecca L., Sathish Kumar M., Senthilvelan T.,GC-MS study of phytochemicals in black gram using two different organic manures,Journal of Chemical and Pharmaceutical Research,V-4,I-2,PP-1246-1250,Y-2012

16. Soniyapriyadharishni A.K., Ramesh Babu P.B.,Data mining strategies for identification of HNF4A MODY gene using gene prioritize tool,Journal of Chemical and Pharmaceutical Research,V-6,I-3,PP-1126-1133,Y-2014

17. Sharmila S., Jeyanthi Rebecca L., Naveen Chandran P., Kowsalya E., Dutta H., Ray S., Kripanand N.R.,Extraction of biofuel from seaweed and analyse its engine performance,International Journal of Pharmacy and Technology,V-7,I-2,PP-8870-8875,Y-2015

18. Sharmila S., Jeyanthi Rebecca L., Saduzzaman M.,Biodegradation of domestic effluent using different solvent extracts of Murraya koenigii,Journal of Chemical and

Pharmaceutical Research,V-5,I-2,PP-279-282,Y-2013

19. Jeyanthi Rebecca L., Sharmila S., Das M.P., Seshiah C.,Extraction and purification of carotenoids from Research,V-6,I-4,PP-594-598,Y-2014

20. Krishnamoorthy P., Praveen Kumar P.K., Ramesh Babu P.B.,Community based evaluation of phenylthiocarbamide (PTC) sensitivity and Dermatoglyphics as a genetic marker in Tamilnadu, India,International Journal of Pharmacy and Technology,V-5,I-3,PP-5705-5712,Y-2013

21. Sharmila S., Jeyanthi Rebecca L.,GC-MS Analysis of esters of fatty acid present in biodiesel produced from Cladophora vagabunda,Journal of Chemical and Pharmaceutical Research,V-4,I-11,PP-4883-4887,Y-2012

22. Sinha S., Rajasulochana P., Ramesh Babu P.B., Krishnamoorthy P.,Comparative modelling of shikimate kinase $(\mathrm{M} \mathrm{Tb})$ and molecular docking studies of its known inhibitors, Research Journal of Pharmaceutical, Biological and Chemical Sciences,V-4,I-3,PP-715-720,Y-2013

23. Jeyanthi Rebecca L., Dhanalakshmi V., Sharmila S.,Effect of the extract of Ulva sp on pathogenic microorganisms, Journal of Chemical and Pharmaceutical Research,V-4,I-11,PP-4875-4878,Y-2012

24. Sharmila S., Jeyanthi Rebecca J.,A comparative study on the degradation of leather industry effluent by Marine algae,International Journal of Pharmaceutical Sciences Review and Research,V-25,I-2,PP-46-50,Y-2014

25. Ramesh Babu P.B., Krishnamoorthy P., Gayathri G.,Identification of drug target site on citrate synthase of food pathogen - Campylobacter jejuni,Research Journal of Pharmaceutical, Biological and Chemical Sciences, V-4,I-1,PP-618-623,Y-2013

26. Sharmila S., Rebecca Jeyanthi L., Saduzzaman M.,Biodegradation of tannery effluent using Prosopis juliflora,International Journal of ChemTech vegetables,Journal of Chemical and Pharmaceutical

Research,V-5,I-5,PP-2186-2192,Y-2013

27. Kumar S., Das M.P., Jeyanthi Rebecca L., Sharmila S.,Isolation and identification of LDPE degrading fungi from municipal solid waste,Journal of Chemical and Pharmaceutical Research,V-5,I-3,PP-78-81,Y-2013

28. Das M.P., Jeyanthi Rebecca L., Sharmila S., Anu, Banerjee A., Kumar D.,Identification and optimization of cultural conditions for chitinase production by Bacillus amyloliquefaciens SM3,Journal of Chemical and Pharmaceutical Research,V-4,I-11,PP-4816-4821,Y-2012

29. Ramesh Babu P.B., Krishnamoorthy P., Rekha R.,Develoment of comprehensive online database model for genes responsible for asthma,Research Journal of Pharmaceutical, Biological and Chemical Sciences, V-4,I-1,PP-865-871,Y-2013

30. Devi M., Jeyanthi Rebecca L., Sumathy S.,Bactericidal activity of the lactic acid bacteria Lactobacillus delbreukii,Journal of Chemical and Pharmaceutical Research,V-5,I-2,PP-176-180,Y-2013

31. Ramesh Babu P.B., Miller T.L., Chidekel A., Shaffer T.H.,Clara cell protein mediates secretion of proteins, IL-8 and IL-6 in human airway epithelial cell line Calu-3 exposed to hyperoxia,Journal of Chemical and Pharmaceutical Research,V-4,I-6,PP-3164-3170,Y-2012

32. Bhuvaneswari B., Hari R., Vasuki R., Suguna,Antioxidant and antihepatotoxic activities of ethanolic extract of Solanum torvum,Asian Journal of Pharmaceutical and Clinical Research,V-5,I-SUPPL. 3,PP-147-150,Y-2012

33. Abraham Samuel F., Mohan V., Jeyanthi Rebecca L.,Physicochemical and heavy metal analysis of sugar mill effluent,Journal of Chemical and Pharmaceutical Research,V-6,I-4,PP-585-587,Y-2014

34. Narayani P.C., Anbu J., Vasuki R., Hari R.,Invitro and invivo anti-arthritic activity of combined ethanolic extracts of Calotropis gigantea and Cardiospermum halicacabum in Wistar rats,Journal of Natural Remedies,V-14,I-1,PP-58-66,Y-2014

35. Paul Das M., Jeyanthi Rebecca L., Sharmila S., Anu, Banerjee A., Kumar D.,Identification and optimization of cultural conditions for chitinase production by Bacillus amyloliquefaciens SM3,Journal of Chemical and Pharmaceutical Research,V-4,I-12,PP-4969-4974,Y-2012

36. Vasuki R., Hari R., Pandian S., Arumugam G.,Hepatoprotective action of ethanolic extracts of eclipta alba and piper longum linn and their combination on CCL 4 induced hepatotoxicity in rats,International Journal of Pharmacy and Pharmaceutical Sciences,V-4,I-SUPPL.1,PP-455-459,Y-2012

37. Saduzaman M., Sharmila S., Jeyanthi Rebecca L.,Efficacy of leaf extract of Moringa oleifera in treating domestic effluent,Journal of Chemical and Pharmaceutical Research,V-5,I-2,PP-139-143,Y-2013

38. Senthil Kumar K., Vasuki R., Priya R.,Green synthesis, pegylation of silver nano herbal complexand study of its anti-mutagenicity activity,International Journal of Pharmacy

Technology, V-8,I-2,PP-12130-12143,Y-2016

39. Srivastava S., Seethalakshmi I., Jeyanthi Rebecca L.,Antimicrobial and antioxidant properties of cissus quandrangularis,Journal of Chemical and Pharmaceutical Research,V-5,I-5,PP-131-134,Y-2013

40. Gireeshan M.G., Vasuki R., Krishnakumar T.,High power production from elephantâ€ $€^{\mathrm{TM}_{\mathrm{S}}}$ urine,International Journal of Pharmacy and Technology,V-6,I-2,PP-6714-6718,Y-2014 
41. Jeyanthi Rebecca L., Dhanalakshmi V., Sharmila S., Das M.P.,In vitro antimicrobial activity of Gracilaria SP and Enteromorpha SP,Research Journal of Pharmaceutical, Biological and Chemical Sciences V-4,I-1,PP-693-697,Y-2013

42. Jeyanthi Rebecca L., Dhanalakshmi V., Thomas T.,A comparison between the effects of three algal extracts against pathogenic bacteria,Journal of Chemical and Pharmaceutical Research,V-4,I-11,PP-4859-4863,Y-2012 